\title{
GPS の世界こぼれ話
}

杉浦邦朗*

アラスカ原油を満載してアラスカ州バルジーズ港を 出港する大型タンカーは，ただでさえ通航が困難な同 港南方の狭水道（第 1 図）を通過して南下しますが, この時, 各船の船長は GPS を使用してここを航行す るといいます。ところが，二の狭水道で，1989年 3 月 24日に, エクソン・バルジーズ号が座礁し, 42.000kl の 原油を流出させるという事故が発生しました。この時, 同船の船長は衛星の一つが僅かに違った位置情報を放 送していたことを知らなかったためにこの事故が起き たといいます。ところが事故の 1 時間ほど前に, コロ ラド州のファルコン空軍基地の米空軍 GPS 監視局で はたまたまこの誤差を補正しようとしていたようで す。この事故で, 原油は海岸を污染し, 多量の魚類・ 海獣を殺すという痛ましい結果となったことはご承知 の通りです。これによって，船主たちは数億ドルの補 償を義務づけられることになりました。そこで，この 船の船主は適時の警報を怠った空軍の過失が同号の乗 揚げの原因であるとして，政府を相手に損害賠償の訴 訟を起こしました。

この事件に関係して，通報の有無によって起こった このような事故に対する政府の責任は一体どうなんだ ろうかとか, GPS を使用している私たちは GPSにつ いてどれだけのリスクを負っているのだろうかとか,
私たちは GPS サービスに対して何の対価も払ってい ないのに，このような過失によって起きた損害に対し てアメリカ政府はどこまで責任を負ってくれるのだろ うかとか, 色々の疑問があります。ところが,この GPS システムの開発段階で, 自分自身のリスクにおいて GPS を使用するよう米国防省が私たちユーザーに対 して指導していたことを知っています。しかし，人工 衛星の配置が完全になったと国防省が宣言した以後 は，政府は全ての責務を負い，発生した損害に対して は責任を負うべきではないかと私は考えたい。

また，1983年に，大韓航空007便が，サハリン上空で ソ連によって撃阹された事件が起きたことはまだ記憶 に新しいところです。その事件後に，レーガン大統領 は，同様の事故を未然に防止するために一般ユーザー が GPSが利用できるように図ることを誓い，政府声 明もこのことを繰り返し述べていたように記憶してい ます。しかし, 㛜密な法律的解釈からは, 一般ユーザー に航海用 GPS サービスを提供しなければならないと する法律上の責務はアメリカ政府にはないといいま す。逆に一度そのようなサービスを開始した場合には， 政府は，システムが正確な情報を伝えていることを確 認するに足る有意な方策を取らねばならないと同時 に, システムの運用者は問題発生の際には適時に警報

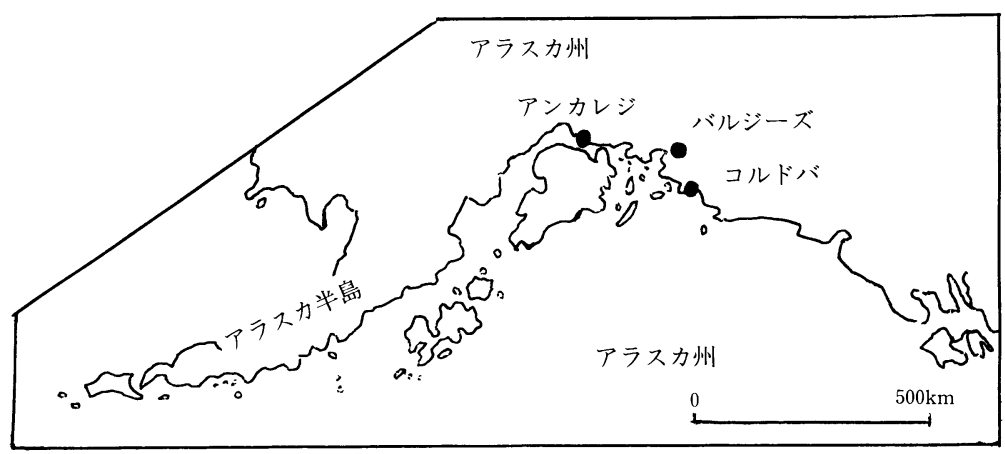

第 1 図 アラスカ州バルジーズ港付近

* 朝日航洋株式会社

「写真測量とリモートセンシング」Vol. 30,No. 3, 1991 
しなければならないという責務が発生するのではない かと思います。ところで，ここでいう「有意な方策」 についてはどう考えればよいのだろうか。例えば,ユ一 ザーの方で船上に 3 台のシステムを置けば，人工衛星 が誤った情報を放送しているかも知れないという恐れ を解消できるかも知れないと云う人がいますが，仮に そうだとして，この場合のように余分なシステムを準 備するということは「有意な方策」とは云えないと見 られています。逆に, 政府が何らかの処置をしたとし て,そのための費用増がほんの僅かであったとすれば, その措置を怠ったことは「有意な方策」を取っていな いとして「政府の急慢」と裁判所は判断すると思いま す。ところが，その時の改善費用が，人工衛星予算を 倍増するようであれば, 裁判所の判断は別のものにな るかも知れません。

ところが，アメリカには，「主権者免責の原理」とい うのがあって, 裁判所が認めない限り告訴出来ないこ とになっています。従って, 何らかの理由で損害が発 生し，それが政府の意慢のためであったと異義を申し 立てる場合には，申請者は政府へのしかるべき告訴理 由を構築しなければなりません。そうでなければ，裁 判所は司法権の及ぶ範囲ではないとして告訴を却下し ます。

アメリカには, 連邦不法行為賠償請求法というのが あって,「個人の不当行為に対して, その場所の法律に 従う義務のある場合には，それが雇用の範囲内での行 為である限りにおいては, 政府職員による過失または 不当な行為もしくは急慢によって生じた財産の損害お よび個人に対する損害または死亡については，アメリ カは，アメリカに対する不服申請の権利を放棄するも のである」と規定されています。

具体的にはこんなケースが考えられます。航空四上 にテレビ塔を表示することは行政機関の自由裁量に当 たりますが，その行政機関が塔を表示しないと決定し た場合には，その結果，航空機がこれに衝突したとし ても，政府は責任を問われることはありません。これ に対して, 航空図上に塔を表示すると決定した場合に は，正確にこれを記載しなければ航空図は記載ミスと なり, この場合は自由裁量とはならず, 裁判所は訴訟 できると判断するでしょう。

GPS の場合も, この自由裁量に関する異義申し立て は重要であって, SA を実行することや, 必要精度の提 供を決定することは, 明らかに自由裁量の行為に当た
ります。従って，良好に信号が得られており，さらに 航空機がコースから外れていないにも拘らずその航空 機が負傷を受けた場合には，パイロットが異義申し立 てても，この法律で告訴は却下されます。これに対し て，コーストガードの GPS 情報センターの通報に 誤った軌道データがあり,これによって受けた損傷は， 政府職員の過失によるものと見なされることになりま す。

また，この法律によれば，例えば，アメリカの主監 視局の過失による誤った GPS データのために，ノル ウエーのユーザーがノルウェー国内で受けた損害に対 しては, 裁判所は訴訟を却下できないことになります。 これとは別の話ですが, 公海または航行水域で, アメ リカ政府によって管理されている財産が損害を受けた か，個人が損害または不慮の死を招いた場合には，別 の法律である海軍省賠償請求法によって，米国は訴訟 を免れないとされています。さらに，全然話が違いま すが，主要な宇宙開発国を含む 60 力国以上の国によっ て署名された「宇宙物体によって引き起こされた損害 に対する責務に関する条約」では，宇宙物体が地球表 面または飛行中の航空機に与えた損害に対しては, 衛 星の打ち上げ国は補償する責務があると規定していま す。一般の法律では過失についての証明を必要としま すが，この条約による補償は，その損害が打ち上げ国 の宇宙物体によって引き起こされたことが明白である ため, ミスまたは過失の立証は必要とされません。ソ 連の宇宙ステーション・ミルが大気中に再突入して， ペルーのリマ地方のコンビニエンス・ストアを破壊し た事故が過去にありましたが，この場合には明らかに 条約が適用されます。しかし，冒頭に述べたエクンン・ バルジーズ号事件のように䛊った GPS デー夕によっ て航行中に発生した損害については，この条約には抵 触しません。こういったケースについては, 条約審議 の段階で，多くの国から数次にわたって異論が述べら れたようですが，アメリカが強く拒否して明白に規定 化されなかったといいます。GPSの場合については, 条約ではその衛星の打ち上げ国については触れておら ず，誰が賠償請求を申し出るかとか，賠償請求を提出 する方法とかについて規定しているに過ぎず，さらに 賠償方法についても規定されていません。従って, GPS をユーザーの義務に取り込むことは, ユーザー自 身の責務であって，民間航空機が長距離を GPSのみ で飛行し，そのデータの間違いのために事故が発生し 
た場合には，事故は運航者の過失によるとして弁償に は難色が示されます。こうした場合には，民間航空機 は GLONASS, 慣性航法システム,レーダー高度計, その他のバックアップシステムを併用すべきであると 云っています。この話は, コロラド州コロラドスプリ ングにある米空軍宇宙司令部の宇宙・国際法所長であ る M. スプラッドリン法学博士の雑誌「GPS WORLD」の論文を参考にしました。

ここでGLONASSのことが出てきましたので，そ れについて簡単に触れることとします。

周知のように, 1978年のアメリカの最初の GPS 試 験衛星の打ち上げに少し遅れて，1982年10月12日に，

ソ連は人工衛星 GLONASS 1 号を打ち上げました。

そして, GLONASS 衛星は現在周回中のものは8個あ

クます。両システムとも，目的がほぼ同じですので，

設計上殆ど類似していますが，第 1 表に示すように， 両システムは, 衛星の軌道やマイクロ波信号の特性な ど微妙に違っております。完全な配置後は, 少なくと も 6 個, 通常は11個位どちらかの衛星が地球上の任意 の地点で視野にあると云います。

GPS と GLONASS の信号の違いは第 2 表に示す通
クで，受信機が，GPS が分割多重受信方式をっている に対して, GLONASS 受信機は, 周波数分割多重受信 方式をとっています。両システムとも，コード関係は 同じですが, GLONASSのコード周波数はGPSの コード周波数の半分ですので, GLONASSの方が精度 がやや悪いこととなっています。GPS 衛星で位置を求 める場合には, 衛星の地心座標を計算してから世界測 地系 WGS 84の值に引き直しますが, GLONASS の場 合は，最終的にソビエト地心系 (SGS 85) の值に換算 しています。

数年前から, 複合システムを望む声があがっていま したが，最近は米ソ間に友愛的・強調的雾囲気が醸し 出されてきたため, GPS およびGLONASSに関する デー夕が,両国間で事務的に交換されるようになって, その開発が可能となってきました。GPS と GLONASS とを複合するということは, 両方の衛星の 信号を同時に追跡でき，両方の衛星の時計と軌道デ一 夕を連結させた受信機を開発することでありますが, GPS およびGLONASS は異なった座標系と時刻系を 持っているため, 複合受信機としては, WGS 84 と SGS 85 との間の関係を繰り込ませ，一方のシステムから他

第 1 表 衛星の軌道 (GPS World, Nov./Dec., 1990)

\begin{tabular}{|l|l|l|} 
& \multicolumn{1}{|c|}{ GPS } & \multicolumn{1}{|c|}{ GLONASS } \\
\hline 軌 道 面 & 各60間隔の 6 面 & 各 $120^{\circ}$ 間隔の 3 面 \\
各面上の衛星数 & 不等間隔の 4 個 & 等間隔の 8 面 \\
軌道面の傾 & $55^{\circ}$ & $64.8^{\circ}$ \\
軌 道 半 径 & $26,560 \mathrm{~km}$ & $25,510 \mathrm{~km}$ \\
軌 道 周 期 & $1 / 2$ 恒星日 $=11 \mathrm{~h} 58 \mathrm{~m}$ & $8 / 17$ 恒星日 $=11 \mathrm{~h} 58 \mathrm{~m}$ \\
同地点周回周期 & 毎恒星日 & 毎 8 恒星日 \\
\hline
\end{tabular}

第 2 表 衛星の信号特性（GPS World, Nov./Dec., 1990)

\begin{tabular}{|c|c|c|}
\hline 項 目 & GPS & GLONASS \\
\hline 搬 送 信 号 & $\begin{array}{l}\mathrm{L}_{1}: 1,575.42 \mathrm{MHz} \\
\mathrm{L}_{2}: 1,227.60 \mathrm{MHz}\end{array}$ & $\begin{aligned} \mathrm{L}_{1} & :(1,602+\mathrm{k} \times 9 / 16) \mathrm{MHz} \\
\mathrm{L}_{2} & :(1,246+\mathrm{k} \times 7 / 16) \mathrm{MHz} \\
& \mathrm{k}: \text { チャンネル数 }\end{aligned}$ \\
\hline コ - ド & 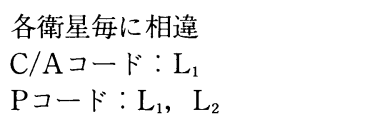 & 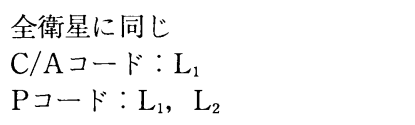 \\
\hline コード周波数 & 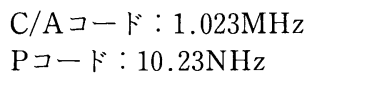 & 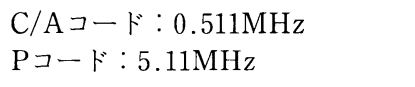 \\
\hline 時刻 データ & $\begin{array}{l}\text { 時刻オフセット, 周波数 } \\
\text { オフセット, 周波数率 }\end{array}$ & 時刻・周波数オフセット \\
\hline 軌道データ & 修正ケプラー軌道要素（毎時） & 衛星位置, 速度, 加速度 (毎30分) \\
\hline
\end{tabular}


のシステムに変換するための変換パラメー夕を受信機 ソフトに含ませればよいことになります。

しかし，都合のよいことは，GPSにSA が処置され ていても，GLONASSの観測を主体にすればよいとい うことであります。さらに有難いことに，国際海事衛 星機構 (INMARSAT) は，次期世代の衛星 INMARSAT-3に GPS と同様な信号を送信することを計画し ていて，これは 4 個の静止衛星からなっていますが, その信号は, 全ての GPS 衛星と GLONASS 衛星の状 態についての情報も送信する計画と云います。

GPSのユーザーに学者グループがいます。彼らは数 百キロ先のミリメートルを論議しようとする連中で, 最大関心事は地震研究における地殼の運動を検出する ことです。先年のロサンゼルス地震域について，サン アンドレアス断層付近の不気味な地殼変動を監視する 目的で，アメリカの地球物理学者たちは，GPS 観測に 没頭しているようです。このチームにイギリスのノッ チングハム大学の測量・宇宙測地研究所長 V.アシュ

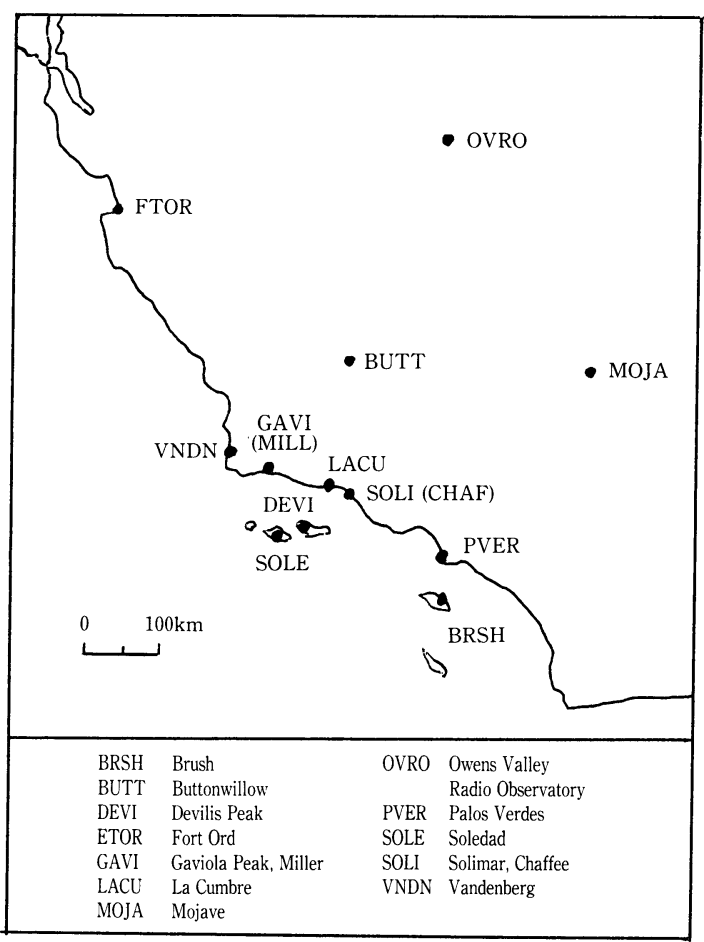

第 2 図国際測地連合の標準データセット カリホルニア州中部地区 (GPS World Nov./Dec., 1990)
ケナッチ教授らも加わり，第 2 図に示す LBI 点を含む 19点の基準点網において，現在 GPS の観測を続けて います。この観測で彼らが得た結果の一部は第 3 図の 通りですが，観測の精度に関して，基線長および高さ についてのばらつき ( $\mathrm{mm}$ 単位の平均自乗詥差による) は基線長についての結果は小さいが，高さについては 可成り大きく，その值は $9 \mathrm{~mm} \pm 0.06 \mathrm{ppm}$ で，しかも 距離とともに増加しているといいます。1990年に，名 古屋大学, 東京大学, 静岡大学等のグループが中部・ 関東地区の南部において，アメリカチームと同様な GPS 干渉測位を行っていますが, 基線長について同様 の結果を得ており, VLVI またはSLR と匹敵する精度 で，地殻変動およびプレートテクトニクスの監視が出 来るとの見通しを得たと彼らは云っています。このよ うな観測結果のための GPS 処理パッケージは，いま， アメリカのマサチュセッツ工科大学とジェット推進研 究所，イギリスのノッチングハム大学その他で開発さ れています。
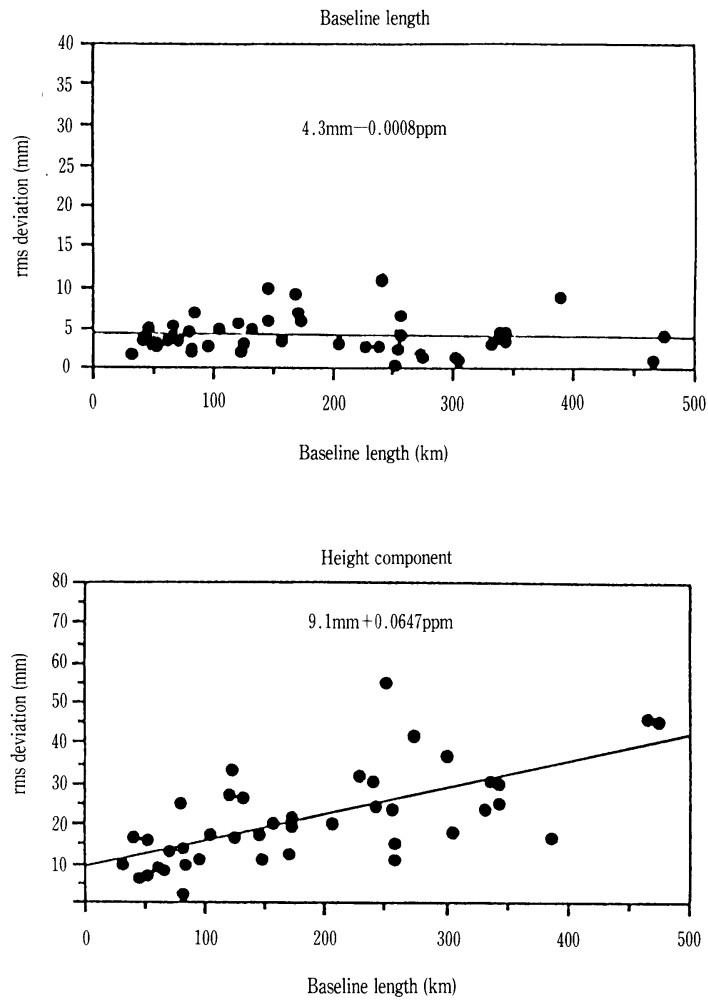

第 3 図 基線長と高さについての信頼性 (GPS World, Nov./Dec., 1990) 